\title{
Jejunostomy Site
}

National Cancer Institute

\section{Source}

National Cancer Institute. Jejunostomy Site. NCI Thesaurus. Code C122647.

A surgically created external opening into the jejunum. 